\title{
Ultrastructural Characteristics of Sulfolobus acidocaldarius
}

\author{
By MICHAEL A. MCCLURE * AND RALPH W. G. WYCKOFF \\ ${ }^{1}$ Department of Plant Pathology, University of Arizona, Tucson, Arizona 85721, U.S.A. \\ ${ }^{2}$ Duval Corporation, 4715 East Fort Lowell Road, Tucson, Arizona 85712, U.S.A.
}

(Received 27 April 1981; revised 10 September 1981)

Isolates of Sulfolobus acidocaldarius from thermal areas in the United States and New Zealand were examined. Cell shape was growth phase-dependent and pleomorphism was more characteristic of certain isolates than of others. Cells prepared for electron microscopy by means which avoided centrifugation exhibited the lobate structure typical of this organism. Actively growing cells attached to carbon substrates by means of an extensive system of pseudopodia-like appendages when the culture medium was agitated.

\section{INTRODUCTION}

Sulfolobus acidocaldarius, a thermophilic prokaryote, was first isolated by Brock et al. (1972) from acid hot-springs at Yellowstone National Park. Its name, in part, was chosen to describe the irregular lobe-shaped character of the organism. While the lobate structure has been challenged as an artefact of centrifugation (de Rosa et al., 1974), Weiss (cited in Brock, 1978) has cogently defended the original description and indicated that lobation, or the incidence of lobation was a function of the growth phase. Nevertheless, the notion persists that the bizarre form of the cell is due to its plasticity and deformation during high-speed centrifugation (Berry \& Murr, 1979).

Our interest in Sulfolobus acidocaldarius grew from a search for organisms more efficacious than thiobacteria in attacking chalcopyrite (Wyckoff, 1975; Wyckoff \& Davidson, 1977) and from the likelihood that acidophilic thermophiles may represent survivors of early forms of life. The purpose of the present study was to show whether the lobate nature of the organisms we observed in numerous isolates was typical of those isolates or was an artefact. Centrifugation either was avoided or its effects were minimized by fixation prior to centrifugation. In addition, since Weiss (cited in Brock, 1978) has implicated morphological changes associated with growth, we have conducted a time-course study of ultrastructure during the exponential phase of growth and for extended periods beyond, during which most of the organisms had reached a stage of senescence.

\section{METHODS}

Cultures were originally isolated from heterotrophic growth on a basal salts medium (Bryner \& Anderson, $1957)$ containing $0.1 \%(w / v)$ yeast extract. For comparative purposes, organisms were examined from a number of thermally active areas of widely separated geographical locations. These included: Mt Lassen Volcanic National Park, U.S.A.; Yellowstone National Park, U.S.A.; Hawaii Volcanoes National Park, U.S.A.; and various locations around Rotorua, New Zealand. Established cultures were maintained either autotrophically on the above medium $\left(70{ }^{\circ} \mathrm{C}, \mathrm{pH} 2.2\right)$ to which elemental sulphur had been added or heterotrophically on a basal salts medium $\left(70^{\circ} \mathrm{C}\right.$, pH 2.2) containing $0.1 \%$ yeast extract (Brock et al., 1972).

Three approaches were used to investigate the lobate nature of the isolates: (i) fixation prior to centrifugation; (ii) fixation of cells attached to elemental sulphur particles without centrifugation; (iii) examination of intact cells which had become attached to a carbon substrate. 
Fixation prior to centrifugation was accomplished by adding $25 \%$ (v/v) aqueous glutaraldehyde to heterotrophic cultures at $60-70^{\circ} \mathrm{C}$ to yield a final concentration of $3 \%$ glutaraldehyde. After addition of the fixative, the cultures were kept at $5{ }^{\circ} \mathrm{C}$ overnight before harvesting the cells by centrifugation at $3000 \mathrm{~g}$. Sedimented cells were washed three times with Sorensen's phosphate buffer, pH 7.2, concentrated by centrifugation at $3000 \mathrm{~g}$ and postfixed in $1 \%(\mathrm{w} / \mathrm{v})$ osmium tetroxide in phosphate buffer. Postfixation was followed by a water rinse and encapsulation in $2 \%(\mathrm{w} / \mathrm{v})$ agar. Small blocks $(1 \times 1 \times 1 \mathrm{~mm})$ of agar containing the bacteria were dehydrated in an acetone series and embedded in Spurr's low viscosity resin which was then polymerized at $70^{\circ} \mathrm{C}$ for $10 \mathrm{~h}$. Silver sections were cut and mounted on carbon-coated grids for electron microscopy at $75 \mathrm{kV}$ in an Hitachi $\mathrm{H}-500$ electron microscope.

Centrifugation was avoided by removing small particles of elemental sulphur from $72 \mathrm{~h}$ cultures and fixing them in $3 \%$ glutaraldehyde for $4 \mathrm{~h}$. Postfixation, dehydration and electron microscopy were performed as described above. Sufficient numbers of bacteria were associated with the sulphur particles to identify them in thin sections, although the particles themselves were not well infiltrated with resin and sectioned poorly.

Intact bacteria were examined by allowing them to become attached to a carbon substrate on 300 mesh gold grids. The grids were held in place on glass microscope slides with small strips of double-sided cellophane tape, and the slides were submerged in liquid cultures of the organism contained in $150 \mathrm{ml}$ bottles. Attachment to the carbon substrate was induced by incubating the bottles for $72 \mathrm{~h}$ at $70^{\circ} \mathrm{C}$ in a reciprocating water bath operating at 54 cycles $\min ^{-1}$. Bacteria that had not adhered to the grids after $72 \mathrm{~h}$ were removed by placing the grids in fresh, sterile medium and shaking for an additional $2 \mathrm{~h}$. Attached bacteria were fixed in situ by immersing the grids in $3 \%$ glutaraldehyde, postfixed in $1 \%$ osmium tetroxide, rinsed with water and air-dried.

Attachment was also induced by placing a drop of fluid from an exponential phase culture on a carbon-coated grid and, after a few minutes, fixing and dehydrating the cells, as above. They were then dried by the critical point method from acetone using $\mathrm{CO}_{2}$ as the transitional fluid. Dried cells on grids were shadow-cast with platinum in a vacuum evaporator at a shadowing angle of $30^{\circ}$.

To determine the influence of the growth stage on bacterial morphology, heterotrophic cultures of two isolates (H4 from Hawaii and NZ2 from New Zealand) were incubated at $70^{\circ} \mathrm{C}$ and harvested 2,8 and $20 \mathrm{~d}$ after inoculation. Fixation prior to centrifugation and electron microscopy were carried out as described above.

\section{R.ES ULTS}

Fixation prior to centrifugation yielded preparations which did not differ significantly from those described elsewhere (Brock et al., 1972; Weiss, 1974) and processed by different methods. The cells were pleomorphic and exhibited varying degrees of irregularity in cross-sectional outline. Of the 11 isolates examined, however, some were more lobate than others. Thus, during the early phase of growth, isolate $\mathrm{H} 4$ contained a high percentage of cells which appeared similar to those observed by de Rosa et al. (1974) in preparations obtained by centrifugation (Fig. 1c). Cells of isolate NZ2 examined $48 \mathrm{~h}$ after inoculation were still lobed but much more regular in outline (Fig. 1a). As the cultures aged, an increasing proportion of the cells had an irregular shape (Fig. $1 b$ ). Lysis of cells also occurred and after $20 \mathrm{~d}$ most of the cells were devoid of contents or contained only remnants of cytoplasm. Cell wall structure was not affected by ageing. Subunit size remained constant and, for the most part, the cell walls of intact cells maintained their original shape, though the walls of lysed cells had a tendency to fold in upon themselves at the broken surface (Fig. 1b). Another feature of ageing cultures was the appearance of very large cells (Fig. 1 $d$ ). These appeared normal except for their size, which was up to five times that of exponential phase cells.

Cells attached to crystals of elemental sulphur were also highly lobed and indistinguishable from cells fixed prior to centrifugation (Fig. $2 a$ ). Some of these cells (Fig. $2 b$ ) formed numerous, but delicate, pilus-like structures.

When exponential phase cultures were allowed to settle on carbon-coated grids, some of the cells adhered to the substrate and persisted through fixation and critical point drying. These cells, when shadow-cast with platinum, revealed the typical lobate structure in three-dimensional relief. Flattening of the cells against the substrate was not observed (Fig. $2 d$ ). Longer periods of exposure, with the grids immersed for $72 \mathrm{~h}$ in agitated culture medium, resulted in the production of pseudopodia-like holdfasts. Where cells attached near a rift in the carbon-film substrate these appendages spanned a gap of $0.5 \mu \mathrm{m}$ or more (Fig. $2 c$ ). These structures were not apparent in bacteria associated with particles of elemental sulphur. 

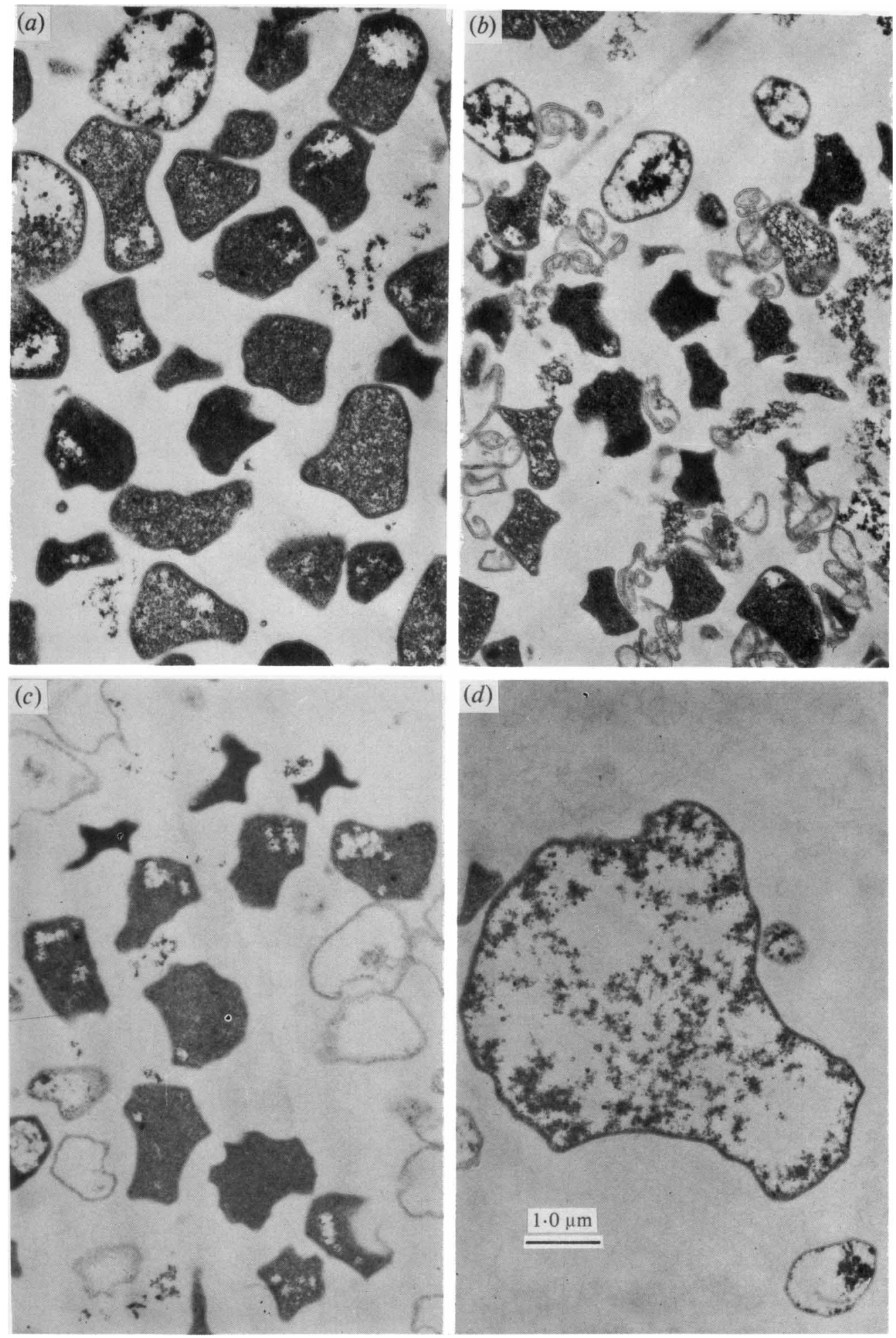

Fig. 1. Thin sections of Sulfolobus acidocaldarius at different stages of growth, fixed prior to centrifugation: (a) isolate NZ2, $48 \mathrm{~h} ;(b)$ isolate NZ2, $20 \mathrm{~d}$; (c) isolate $\mathrm{H} 4,48 \mathrm{~h} ;(d)$ isolate $\mathrm{H4}, 20 \mathrm{~d}$. All parts of the figure are at the same magnification. Note the extreme size of the cell in $(d)$. 
(a)

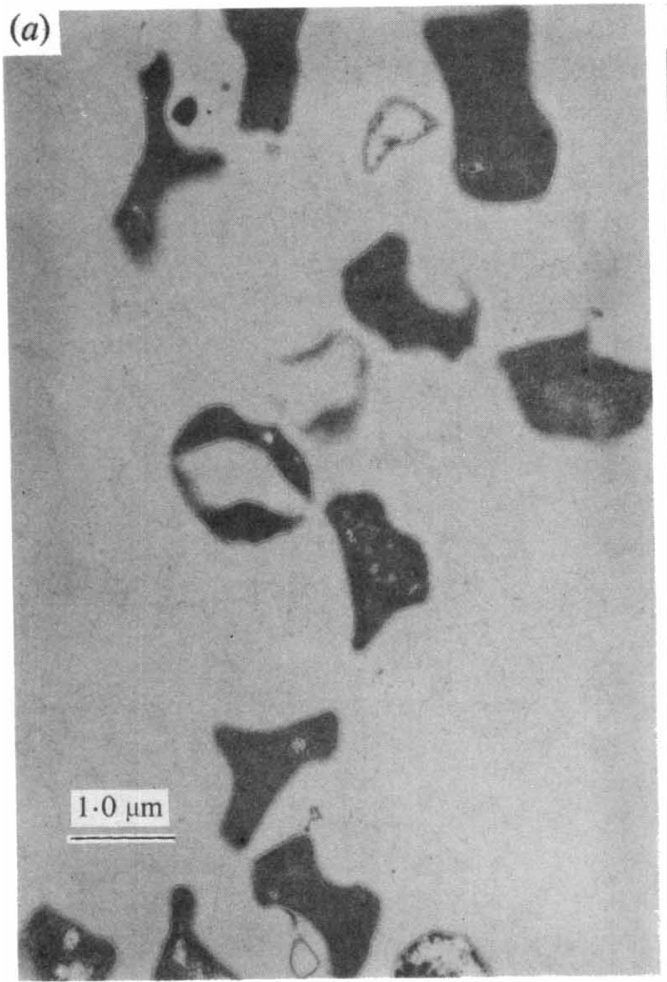

(c)
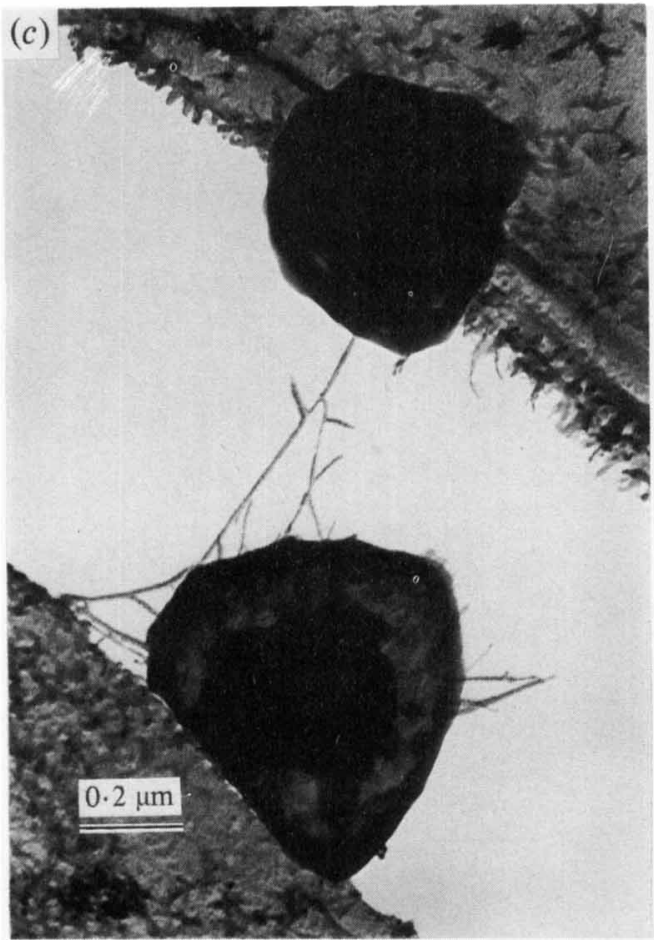
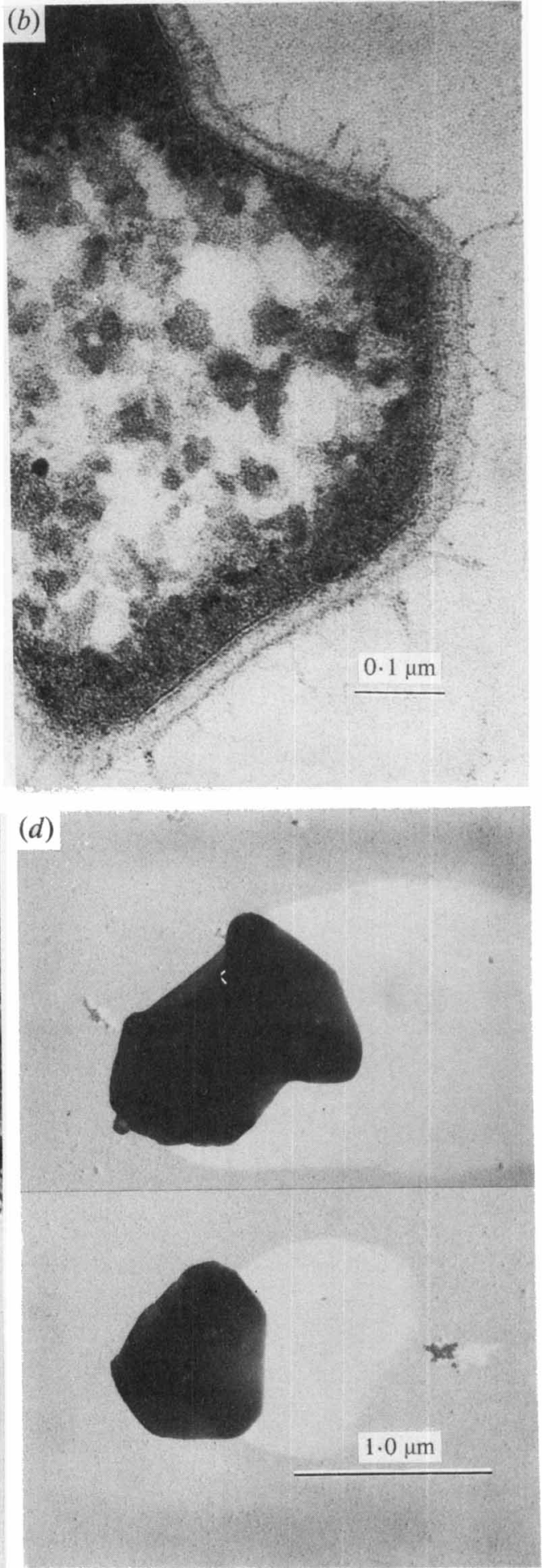

Fig. 2. Sulfolobus acidocaldarius attached to substrates. $(a, b)$ Thin sections of cells associated with particles of elemental sulphur: note the pilus-like structures in $(b) .(c, d)$ Platinum-shadowed cells attached to a carbon film: $(c)$ holdfasts bridging the gap between two cells $72 \mathrm{~h}$ after inoculation; $(d)$ cells adhering to carbon film after $3 \mathrm{~min}$ exposure. 
DIS C US SION

While the irregular, lobate shape of Sulfolobus acidocaldarius was accentuated in older cultures, fixation prior to centrifugation or treatments not involving centrifugation did not significantly alter the basic form of the organism. Certain isolates showed a greater tendency towards bizarre shapes than did others. We concur with Weiss (cited in Brock, 1978), therefore, that the highly lobed type of cell shown by some workers (Berry \& Murr, 1979) is not an artefact, but occurs in most populations in varying proportions. Clearly, some isolates show a greater tendency towards lobation than do others, and it is of interest to note that isolate NIT-3 of de Rosa et al. (1974), which is nearly spherical, differs significantly from more-lobed isolates with respect to the \% guanosine-cytosine in preparations of its DNA. We have further noticed that certain isolates grow much more rapidly than do others under identical conditions, despite the fact that ultrastructural features are virtually indistinguishable. Such observations, taken together with the description of temperature variant strains (Mosser et al., 1974) as well as serologically distinct isolates (Bohlool \& Brock, 1974), support the conclusion of de Rosa et al. (1974) that the considerable variation within the group Sulfolobus probably represents polyphyletic relationships and should be viewed as indications for taxonomic distinction. Holdfasts of Sulfolobus attached to carbon films differed markedly from those reported by Weiss, who considered the holdfasts of Sulfolobus attached to sulphur crystals to be pili (Weiss, 1973). While those of cells attached to sulphur were uniform in diameter and only slightly bent or curved, holdfasts on carbon films were of widely varying diameter and branched. The significance of this phenomenon is yet to be explored.

This work was supported by a U.S. Public Health Service Grant no. 5R01 DEO4635, National Institutes of Health, and the National Science Foundation (no. PCM174-17288 AO1).

\section{REFERENCES}

BERRY, V. K. \& MURR, L. E. (1979). Uitrastructure of the cell envelope of an acidophilic thermophile: comparison with $T$. ferro-oxidans and a Sulfolobus-like microorganism. Proceedings of the 37th Annual Meeting of the Electron Microscope Society of America, 260-261.

Bohlool, B. B. \& BROCK, T. D. (1974). Population ecology of Sulfolobus acidocaldarius. II. Immunoecological studies. Archives of Microbiology 97, 181-194.

Brock, T. D. (1978). Thermophilic Microorganisms and Life at High Temperature, pp. 123-124. New York: Springer Verlag.

Brock, T. D., Brock, K. M., Belly, R. T. \& Weiss, R. L. (1972) Stlfolobus: a new genus of sulfuroxidizing bacteria living at low $\mathrm{pH}$ and high temperature. Archiv für Mikrobiologie 84, 54-68.

Bryner, L. C. \& ANDERson, R. (1957). Microorganisms in leaching sulfide minerals. Industrial and Engineering Chemistry 49, 1721-1724.

Mosser, J. L., Mosser, A. G. \& Brock, T. D. (1974). Population ecology of Sulfolobus acidocaldarius. I.
Temperature strains. Archives of Microbiology 97, 169-179.

de Rosa, M., Gambacorta, A., Millonig, G. \& Bu'LOCK, J. D. (1974). Convergent characters of extremely thermophilic acidophilic bacteria. Experientia 30, 866-868.

WEISS, R. L. (1973). Attachment of bacteria to sulphur in extreme environments. Journal of General Microbiology 77, 501-507.

WEISS, R. L. (1974). Subunit cell wall of Sulfolobus acidocaldarius. Journal of Bacteriology 118, 275284.

Wyckoff, R. W. G. (1975). Les protéines fossiles et la vie primitive. Comptes rendus hebdomadaire des séances de l'Académie des sciences 280, 147 153.

Wyckoff, R. W. G. \& Davidson, F. D. (1977). The composition, morphology and action upon chal copyrite of autotrophs recovered from fumaroles. Gesellschaft für Biotechnologische Forschung $\mathrm{mbH}$. Conference on Bacterial Leaching, Braunschweig, 67-74. 